\title{
Manajemen Lembaga Pendidikan dalam Pelaksanaan Pembelajaran Tatap Muka Terbatas
}

\author{
Ramdanil Mubarok \\ Manajemen Pendidikan Islam, Tarbiyah, STAI Sangatta, Kutai Timur, Indonesia \\ Email: danil.education@gmail.com
}

Informasi Artikel

Diterima : 04-12-2021

Revisi : 16-12-2021

Diterbitkan : 20-01-2022

Keywords: management educational institutions limited face-to-face learning

\begin{abstract}
The Covid-19 pandemic has shown a downward trend, allowing for limited face-to-face learning. The purpose of writing the article is to analyze the concept of limited face-to-face learning and the management of its implementation. The method used is a qualitative research method with the type of library research (library research). The result is that the concept of implementing face-to-face learning (PTM) is limited to the Covid-19 pandemic, which is a learning model carried out in educational institutions face-to-face which is limited to the number of students, a number of meetings, meeting hours and subject matter with terms and conditions that have been set. The management of the implementation of face-to-face learning is limited, namely by careful planning, proper organization, effective and efficient implementation, as well as intense supervision by monitoring, having evaluation instruments, and reporting. It is hoped that through this article the implementation of limited face-to-face learning can be carried out in accordance with expectations, and is able to provide suggestions for improvement.
\end{abstract}

\begin{abstract}
Abstrak
Pandemi Covid-19 sudah menunjukkan tren yang menurun sehingga memungkinkan pelaksanaan pembelajaran tatap muka terbatas. Tujuan penulisan artikel yaitu untuk menganalisis konsep pembelajaran tatap muka terbatas, dan manajemen pelaksanaannya. Metode yang digunakan yaitu metode penelitian kualitatif dengan jenis penelitian kepustakaan (library research). Hasilnya yaitu konsep pelaksanaan pembelajaran tatap muka (PTM) terbatas pada masa pandemi Covid-19 merupakan model pembelajaran yang dilaksanakan di lembaga pendidikan secara tatap muka yang dibatasi pada jumlah siswa, jumlah pertemuan, jam pertemuan dan materi pelajaran dengan syarat dan ketentuan yang telah ditetapkan. Adapun manajemen pelaksanaan pembelajaran tatap muka terbatas yaitu dengan perencanaan yang matang, pengorganisasian yang tepat, pelaksanaan yang efektif dan efisien, serta pengawasan yang intens dengan melakukan pemantauan, adanya instrumen evaluasi, dan pelaporan. Harapannya melalui artikel ini pelaksanaan pembelajaran tatap muka terbatas dapat dilaksanakan sesuai dengan harapan, dan mampu memberikan saran perbaikan.
\end{abstract}

Kata Kunci: manajemen, lembaga pendidikan, PTM terbatas

\section{PENDAHULUAN}

Model pembelajaran online harus segera dihentikan dan beralih ke model pembelajaran tatap muka. Walaupun sebenarnya pembelajaran tatap muka belum sepenuhnya dapat dilaksanakan terlebih di daerah-daerah yang masih tinggi penyebaran Covid-19 [1]. Kekhawatiran tersebut bukan tanpa alasan karena dengan model pembelajaran online dapat berdampak pada risiko dampak sosial negatif yang berkelanjutan [2]. Bukan hanya itu, namun juga dapat berdampak pada kualitas pendidikan dan tumbuh 
kembang anak serta hak-hak yang ada pada diri anak [3]. Terdapat tiga alasan penting mengapa lembaga pendidikan harus beralih dari model pembelajaran online ke model pembelajaran tatap muka. Pertama, untuk menghindari ancaman putus sekolah. Kedua, untuk menghindari turunnya kualitas pencapaian pembelajaran anak. Ketiga, untuk menghindari risiko aspek psikis dan sosial anak [4].

Penanganan pandemi Covid-19 sudah menunjukkan tren yang positif sehingga memungkinkan pelaksanaan pembelajaran tatap muka. Terlebih lagi jika melihat tren penyebaran Covid-19 di luar pulau Jawa dan Bali. Berkaitan dengan hal tersebut, pemerintah melalui Surat Keputusan Bersama (SKB) 4 Menteri pada awal tahun 2021, tepatnya pada bulan Maret telah mengatur akselerasi pelaksanaan pembelajaran tatap muka dengan model pembelajaran tatap muka terbatas [5]. Pembelajaran tatap muka terbatas dapat dilaksanakan tentunya dengan tetap menerapkan protokol kesehatan [6] dengan tetap memakai masker, menjaga jarak, mencuci tangan, menjauhi kerumunan dan mengurangi mobilitas. Termasuk salah satu syarat wajib dalam pembelajaran tatap muka terbatas adalah telah melakukan vaksin bagi pendidik dan peserta didik.

Kebijakan pembelajaran tatap muka terbatas yang ditetapkan oleh pemerintah melalui Kemendikbud menuai pro dan kontra, hal tersebut terjadi karena kurangnya pemahaman masyarakat tentang istilah pembelajaran tatap muka terbatas. Anggapan-anggapan yang berkaitan dengan pembelajaran tatap muka terbatas tersebut sangatlah beragam. Diantara masyarakat dan wali murid menganggap bahwa pembelajaran tatap muka terbatas akan membuka sekolah dan akan melaksanakan pembelajaran tatap muka seperti biasanya. Padahal anggapan-anggapan yang demikian merupakan anggapan yang keliru dan perlu diluruskan supaya masyarakat umum khususnya wali murid tidak salah paham berkaitan dengan pembelajaran tatap muka terbatas.

Pembelajaran tatap muka terbatas merupakan model pembelajaran yang dilaksanakan di sekolah dengan model tatap muka yang dibatasi dengan syarat dan ketentuan yang telah disepakati [7], sehingga pembelajaran tatap muka tidak dapat dilaksanakan dengan normal seperti pembelajaran sebelum adanya pandemi Covid-19. Pembelajaran tatap muka terbatas mengatur jumlah peserta didik [8] sehingga jumlah peserta didik lebih sedikit dari jumlah normal. Karena harus mengatur jarak kursi dan meja di dalam kelas sesuai dengan protokol kesehatan. Berkaitan dengan intensitas pertemuan juga demikian, jam pelajaran dan hari masuk sekolah juga disesuaikan dengan jumlah peserta didik di lembaga pendidikan [9]. Artinya, setiap peserta didik tidak harus masuk sekolah setiap hari dan tidak harus masuk sekolah full waktu. Demikian juga materi pelajaran, dalam pembelajaran tatap muka juga dibatasi ada materi-materi pelajaran yang pokok-pokok saja sehingga materi pembelajaran dalam satu mata pelajaran juga dikurangi. Pelaksanaan Pembelajaran tatap muka terbatas juga harus mendapatkan persetujuan dari orang tua peserta didik [10]. Oleh karena itu lembaga pendidikan sebagai penyelenggara pendidikan tatap muka harus memberikan opsi-opsi lain ketika orang tua peserta didik tidak setuju apabila anak-anaknya belajar tatap muka. Dengan demikian maka lembaga pendidikan harus menyiapkan pembelajaran mode online untuk memberikan kesempatan belajar yang sama bagi peserta didik yang tidak tidak ikut belajar tatap muka.

Berkaitan dengan pembelajaran tatap muka pada masa pandemi pernah dilakukan oleh beberapa peneliti sebelumnya, diantaranya penelitian yang dilakukan oleh Emik dkk yang konsen pada salah satu fungsi manajemen yaitu perencanaan, dimana ia meneliti tentang perencanaan pebelajaran tatap muka pada masa pandemi, hasilnya bahwa sebelum melaksanakan pembelajaran tatap muka maka warga sekolah harus: a) sudah divaksin b) menjaga imunitas, c) mematuhi protokol kesehatan [11]. Penelitian selanjutnya dilakukan oleh Hendrik yang fokus pada sistem manajemennya. Hasilnya, bahwa dengan menerapkan sistem manajemen pada pembelajaran tatap muka dapat memudahkan proses pembelajaran, mengefektifkan waktu, dan mengefisienkan biaya bagi peserta didik dan pendidik untuk mencapai tujuan yang telah ditetapkan [12]. Ada juga penelitian dari Mitra Kasih La Ode dkk. yang konsen pada pelaksanaannya. Hasilnya bahwa dalam pelaksanaan pembelajaran tatap muka terbatas mengikuti panduan pemerintah dan diterapkan secara sistematis dengan memadatkan materi pelajaran, menggunakan metode yang tidak melibatkan siswa sehingga tidak terjadi kontak antara siswa dan guru [13]. Begitu juga dengan penelitian yang dilakukan oleh Husna dan Sugito, dimana penelitiannya menitikberatkan pada eksplorasi penerapan pembelajaran tatap muka terbatas. Hasilnya dalam mengeksplor penerapan pembelajaran tatap muka maka lembaga pendidikan harus mematuhi pedoman pembelajaran tatap muka, melakukan kerjasama antara lembaga, dan melibatkan orang tua siswa [14].

Berdasarkan fenomena sosial dan literatur review di atas maka yang menjadi fokus artikel ini yaitu bagaimana konsep pembelajaran tatap muka terbatas, dan bagaimana manajemen pelaksanaan pembelajaran tatap muka terbatas? Penelitian ini diharapkan mampu mendeskripsikan konsep pembelajaran tatap muka terbatas, manajemen pelaksanaan pembelajaran, serta kendala-kendalanya 
sehingga pelaksanaan pembelajaran tatap muka terbatas dapat dilaksanakan sesuai dengan harapan, dan mampu memberikan saran perbaikan terkait kendala yang dihadapi.

\section{METODE PENELITIAN}

Metode penelitian yang digunakan dalam artikel ini yaitu metode penelitian kualitatif dengan jenis studi pustaka (library research) [15]. Penelitian kepustakaan merupakan penelitian yang menjadikan literature sebagai basis data [16]. Penulis melakukan analisis dengan terlebih dahulu menentukan topik artikel, kemudian mencari informasi yang berkaitan dengan topik, dan menentukan fokus artikel. Selanjutnya penulis mengumpulkan buku-buku elektronik, artikel jurnal, peraturan pemerintah, dan laporan hasil penelitian yang relevan dengan tema artikel. Selanjutnya penulis membuat catatan-catatan kecil pada bagian yang diperlukan untuk ditampilkan di dalam artikel. Apa yang dilakukan penulis tersebut telah sesuai dengan tahapan dalam penelitian kepustakaan Kuhlthau dalam Mirzaqon yaitu memilih topik, mengeksplor informasi, menentukan fokus, mengumpulkan sumber data, menyajikan data, dan membuat laporan [17].

\section{HASIL DAN PEMBAHASAN}

\subsection{Konsep Pembelajaran Tatap Muka Terbatas}

Pembelajaran tatap muka terbatas merupakan sebuah konsep baru yang berkembang selama adanya pandemi Covid-19 [8]. Selama adanya pandemi Covid-19 segala bentuk kegiatan yang menimbulkan kerumunan sedapat mungkin dihindari, hal tersebut dilakukan dengan tujuan untuk mengendalikan penyebaran Covid-19. Sejak tahun ajaran baru 2021/2022 pemerintah mengenalkan suatu istilah dalam dunia pendidikan. Istilah-istilah baru di dalam dunia pendidikan tentunya harus dapat dipahamkan dan dijelaskan kepada masyarakat luas sehingga tidak menimbulkan pengertian dan persepsi yang berbeda di tengah masyarakat. Terdapat beberapa konsep yang berbeda dalam memahami istilah pembelajaran tatap muka terbatas. Ketika berbicara tentang pembelajaran tatap muka maka setiap individu akan memahaminya sebagai sebuah proses pembelajaran yang dilakukan antara seorang pendidikan dan peserta didik dengan bertemu langsung dan berinteraksi antara satu dengan yang lainnya pada lokasi yang sama. Konsep pembelajaran tatap muka (PTM) terbatas merupakan proses pembelajaran dalam ruang-ruang kelas di sekolah dimana setiap rombongan belajar dibatasi dari segi jumlah peserta didik sehingga jumlahnya tidak sama dengan jumlah peserta didik pada masa normal.

Jika merujuk pada peraturan pendidikan bahwa setiap rombongan belajar di sekolah terdiri dari 36 siswa [5]. Maka dalam keadaan normal tanpa adanya pandemi Covid-19 maka ruang-ruang kelas yang berada di sekolah itu akan terisi dengan peserta didik dengan jumlah maksimal 36 orang. Ketika pembelajaran dilakukan harus dengan protokol kesehatan yang ketat seperti menjaga jarak, maka setiap kursi dan meja peserta didik di ruang kelas harus mempunyai jarak minimal satu meter. Hal inilah kemudian yang melatar belakangi munculnya istilah pembelajaran tatap muka (PTM) terbatas [18]. Dengan demikian maka dalam pembelajaran tatap muka terbatas setiap ruang kelas hanya terdiri dari 50\% dari jumlah normalnya. Sehingga dalam pembelajaran tatap muka (PTM) terbatas rombongan belajar hanya terdiri dari 18 peserta didik saja.

Dalam pembelajaran tatap muka (PTM) terbatas juga perlu diperhatikan berkaitan dengan intensitas pertemuan, materi pelajaran, dan durasi waktu yang digunakan. Pada pembelajaran tatap muka (PTM) terbatas seorang peserta didik tidak harus mengikuti pertemuan pembelajaran full time. Sehingga lembaga pendidikan harus mengorganisasikan sistem pertemuan dalam pembelajaran tatap muka (PTM) terbatas [19]. Demikian juga dengan materi pelajarannya, lembaga pendidikan sebagai penyelenggara pendidikan harus mempunyai perencanaan yang tepat berkaitan dengan materi pelajaran sehingga pada prosesnya materi pelajaran yang diajarkan di sekolah pada pembelajaran tatap muka (PTM) terbatas dipilih sesuai dengan kebutuhan, maupun skala prioritas.

Hal lain yang perlu dipahami juga berkaitan dengan konsep pembelajaran tatap muka (PTM) terbatas adalah persyaratan pelaksanaan pembelajaran tatap muka (PTM) terbatas dapat dijalankan apabila orang tua peserta didik mengizinkan anak-anaknya untuk mengikuti pembelajaran tatap muka (PTM) terbatas. Apabila orang tua peserta didik tidak siap dan enggan melepaskan anak-anaknya untuk ikut pembelajaran tatap muka (PTM) terbatas, maka lembaga pendidikan harus menyiapkan opsi-opsi. Lembaga pendidikan harus memadukan antara pembelajaran tatap muka (PTM) terbatas dengan pembelajaran jarak jauh. Hal tersebut menjadi solusi alternatif apabila terdapat orang tua peserta didik yang tidak setuju untuk melepaskan anak-anaknya mengikuti pembelajaran tatap muka (PTM) terbatas. Karena memang sebagian orang tua lebih setuju apabila anak-anaknya belajar dari rumah pada masa 
pandemi Covid-19. Tujuannya jelas untuk menghindarkan anak-anaknya kontak langsung dengan teman, guru, dan masyarakat sekolah pada umumnya.

\subsection{Manajemen Pelaksanaan Pembelajaran Tatap Muka Terbatas}

Berkaitan dengan pembelajaran tatap muka (PTM) terbatas di setiap kabupaten atau provinsi tentu memiliki metode, gaya, dan cara dalam melaksanakan pembelajaran tatap muka (PTM) terbatas. Karena dapat dipastikan bahwa setiap provinsi memiliki kebijakan yang berbeda-beda dalam menyikapi pembelajaran tatap muka (PTM) terbatas, sehingga mempengaruhi pola pikir dan pemahamannya tentang pembelajaran tatap muka (PTM) terbatas. Alasan yang menjadi dasar diterapkannya pembelajaran tatap muka (PTM) terbatas pada masa pandemi Covid-19 diantaranya: 1) Dampak penyebaran Covid-19 sudah mulai melandai dan mereda di beberapa daerah. 2) Animo masyarakat yang semakin tinggi untuk menyegerakan pembelajaran tatap muka (PTM) terbatas. 3) Adanya lampu hijau dari pemerintah yang memperbolehkan pembelajaran tatap muka (PTM) terbatas di sekolah [20]. Dalam ilmu manajemen dikenal istilah fungsi-fungsi manajemen yaitu perencanaan, pengorganisasian, pelaksanaan, dan evaluasi [21] dan inti dari manajemen adalah kerjasama [22].

\section{Perencanaan Pembelajaran Tatap Muka (PTM) Terbatas}

Pelaksanaan pembelajaran tatap muka terbatas dapat terlaksana dengan efektif dan efisien apabila didasarkan pada perencanaan yang baik. Perencanaan merupakan sebuah ide yang disusun sebelum melaksanakan suatu kegiatan [23]. Hal urgen pertama yang harus dilakukan dalam pembelajaran tatap muka terbatas adalah perencanaan. Sebuah aktivitas kaitannya dengan proses maupun pengelolaan pembelajaran tatap muka (PTM) terbatas tentu memiliki perencanaan yang matang sehingga memudahkan penerapan fungsi-fungsi manajemen yang lainnya. Dalam perencanaan pembelajaran tatap muka (PTM) terbatas tentu dihadapkan pada persoalan ketatnya peraturan, syarat yang memberatkan. Adapun syarat untuk dapat melaksanakan pembelajaran tatap muka (PTM) terbatas di lembaga pendidikan antara lain [24]: 1) Peserta didik yang boleh mengikuti pembelajaran tatap muka (PTM) terbatas adalah mereka yang sudah Vaksin minimal dosis pertama. 2) Peserta didik yang akan mengikuti pembelajaran tatap muka (PTM) terbatas harus sudah mempunyai izin dan persetujuan orang tua. 3) membuat surat pernyataan tentang kesiapan mengikuti pembelajaran tatap muka (PTM) terbatas.

Dalam pelaksanaannya pembelajaran tatap muka (PTM) terbatas seorang peserta didik harus mengikuti minimal 50\% dari kegiatan tatap muka di kelas bersama tenaga pendidikanya. Aktivitas belajar peserta didik pada pembelajaran tatap muka (PTM) terbatas juga harus berorientasi pada kegiatan praktik, serta seluruh kegiatan pembelajaran tatap muka (PTM) terbatas harus tetap mematuhi protokol kesehatan yang ketat. Hal yang sama tentu juga harus disiapkan oleh lembaga pendidikan berkaitan dengan kesiapan fasilitas. Diantara persiapan sarana dalam pembelajaran tatap muka (PTM) terbatas sebagai berikut [25] : 1) Lembaga pendidikan membuat poster tentang pentingnya penerapan protokol kesehatan dalam pembelajaran tatap muka (PTM) terbatas. 2) Lembaga pendidikan juga harus mempersiapkan pengukuran suhu (thermo gun) yang baik. 3) Lembaga pendidikan menyiapkan tempat mencuci tangan di tempattempat strategis.

\section{Pengorganisasian Pembelajaran Tatap Muka (PTM) Terbatas}

Pengorganisasian merupakan upaya dalam mengoptimalkan segala bentuk sumber daya yang ada untuk mencapai tujuan melalui perencanaan yang matang [26]. Kalau dalam lembaga pendidikan maka pengorganisasian dilakukan untuk mengelola sumber daya manusia sesuai dengan bidang keahliannya untuk mencapai tujuan organisasi yang efektif dan efisien. Pengorganisasian pembelajaran tatap muka terbatas bukan saja pada sumber daya manusianya, namun pada segala bentuk sumber daya yang ada demi efektifnya proses pembelajaran. Pengorganisasian dapat diartikan sebagai suatu lembaga dan kelompok, dan pengorganisasaian dapat juga diartikan sebagai suatu proses. Menurut Handoko pegorganisasian merupakan rincian pekerjaan, pembagaian kerja, pengadaan, dan pengembangan pekerjaan yang dilaksanakan untuk mencapai tujuan [26]. Dengan demikian maka pengorganisasian dalam pembelajaran tatap muka terbatas merupakan segala bentuk pembagian kerja dan rincian proses yang dilaksanakan dalam pembelajaran tatap muka terbatas.

Pembelajaran tatap muka (PTM) terbatas juga perlu diperhatikan berkaitan dengan peserta didik maupun pendidik, diantaranya adalah : 1) Pendidik dan peserta didik harus mencuci tangan dengan sabun atau minimal menggunakan hand sanitizer sebelum masuk ke dalam kelas. 2) Pendidik dan peserta didik harus menggunakan masker kesehatan yang tiga lapis. 3) Pendidik dan peserta didik harus tetap menjaga jarak selama proses pembelajaran berlangsung. 4) Pendidik dan peserta didik tidak meminjam atau 
memberikan pinjaman alat tulis kepada peserta didik yang lain. 5) Pendidik dan peserta didik masuk dan keluar kelas harus tetap mempertahankan jarak antar peserta didik minimal satu meter. Pada poin pengorganisasian ini kemudian lembaga pendidikan sebagai penyelenggara pembelajaran tatap muka (PTM) terbatas harus mengorganisasikan

\section{Pelaksanaan Pembelajaran Tatap Muka (PTM) Terbatas}

Pelaksanaan pembelajaran tatap muka (PTM) terbatas pada masa pandemi Covid-19 ini harus memiliki izin. Lembaga pendidikan sebagai penyelenggara pendidikan hendaknya telah memiliki izin tertulis dari dinas pendidikan setempat. Setelah mendapatkan izin tertulis maka, pembelajaran tatap muka (PTM) terbatas harus dilaksanakan sebaik-baiknya. Dalam pembelajaran tatap muka (PTM) terbatas maka perlu bagi adanya poster tentang protokol kesehatan dan pelaksanaan pembelajaran tatap muka (PTM) terbatas di lingkungan sekitar.

Dalam pembelajaran tatap muka (PTM) harus diperhatikan prinsip-prinsip yang sudah ditetapkan, seperti : Keselamatan peserta didik dan pendidik, kualitas pembelajaran, dan proses pembelajaran yang efektif dan efisien. Artinya keselamatan peserta didik, pendidik, dan tenaga kependidikan merupakan hal yang utama yang harus menjadi perhatian bersama seluruh warga sekolah dalam pembelajaran tatap muka (PTM). Jika melihat penyebaran Covid-19 di kabupaten Kutai Timur pada bulan oktober 2021 sebenarnya sudah menurun sampai pada angka 19 persen [27], namun demikian bukan berarti penerapan protokol kesehatan Covid-19 menjadi longgar.

Kesadaran akan penerapan protokol kesehatan merupakan kunci melindungi diri dan orang lain dari penyebaran covid-19 [28]. Demikian juga dalam proses pembelajaran tatap muka terbatas, lembaga pendidikan harus ikut ambil bagian dalam rangka menertibkan penerapan protokol kesehatan. Dilansir dari WHO, virus COVID-19 dapat menyebar melalui beberapa cara yaitu melalui droplet, kontak fisik, tempat ramai, dan permukaan yang terkontaminasi virus Covid-19, maka pemerintah Indonesia membuat pedoman pencegahan penularan virus Covid-19 yang sering disebut dengan gerakan 5M yaitu:

\section{Mencuci Tangan}

Mengingat penyebaran Covid-19 salah satunya adalah adalah dengan permukaan yg terkontaminasi, maka mencuci tangan menjadi sangat penting karena banyak interaksi bermula pada tangan. Bukan hanya pada saat hendak makan saja, setelah memegang benda, dan setelah bersalaman dengan orang lain pun harus mencuci tangan dengan sabun atau pembersih tangan (hand sanitizer) dengan alkohol setidaknya dengan kadar 60 persen. Maka setiap pendidik dan peserta didik harus membiasakan mencuci tangan saat berada di sekolah dengan baik dan benar.

\section{Memakai Masker}

Salah satu media penularan utama COVID-19 adalah butiran cairan (droplet) dari saluran pernapasan yang terlontar saat seseorang berbicara, batuk, dan bersin. Berdasarkan media penularan tersebut maka hidung dan mulut harus ditutup supaya melindungi diri kita dan orang lain terhindar dari virus Covid-19. Saat ini masker sudah menjadi kebutuhan kesehatan bagi setiap orang, karena itu ada standar pemakaian masker yang harus dipatuhi supaya peran masker sebagai pelindung dari virus dapat berfungsi dengan maksimal.

Standar pemakaian masker yang baik dan benar antara lain [29]: a) Pastikan tangan dalam keadaan bersih saat memegang masker. b) Pastikan tidak terdapat celah antara wajah dan masker serta menutupi mulut, hidung dan dagu ketika menggunakan masker. c) Masker hendaknya mengikuti lekuk hidung dengan cara menekan-nekan masker ketika hendak menggunakannya. d) Gunakan masker yg memenuhi standar (tidak tipis), atau memakai masker ganda lebih baik. e) Lepas masker dari tali belakang, jangan diturunkan ke area dagu atau leher. f) Masker tidak boleh dipakai berulang kali, hendaknya masker dipakai untuk satu kali pakai. d) Untuk masker kain, setelah 1x pemakaian segera cuci dengan deterjen.

\section{Menjaga Jarak}

Menjaga jarak merupakan salah salah satu protokol kesehatan yang perlu dipatuhi. Penting bagi kita untuk menjaga jarak di tempat dan fasilitas umum untuk mencegah penyebaran virus Covid-19. Disebutkan dalam Keputusan Menteri Kesehatan RI untuk menjaga jarak minimal 1 meter dengan orang lain untuk menghindari terkena droplets dari orang yang bicara, batuk, dan bersin [30]. Mengingat bahwa sekolah juga merupakan salah satu tempat umum maka penting untuk mengadakan penyuluhan pada 
siswa. Mengingatkan kembali pada siswa untuk tetap menjaga jarak di lingkungan sekolah supaya meminimalisir penularan Covid-19.

\section{Menjauhi Kerumunan}

Selain tiga hal di atas, menjauhi kerumunan merupakan protokol kesehatan yang juga harus dilakukan. Menurut Kementerian Kesehatan RI, masyarakat diminta untuk menjauhi kerumunan saat berada di luar rumah. Semakin banyak dan sering kita bertemu orang, maka kemungkinan terinfeksi virus corona pun semakin tinggi [31]. Saat telah diberlakukannya pembelajaran tatap muka terbatas, maka peserta didik harus diingatkan untuk menjauhi kerumunan atau bahkan membuat kerumunan di sekolah. Selama hampir satu tahun lebih siswa melaksanakan pembelajaran daring, dan kini mereka sudah diperbolehkan untuk kembali belajar di sekolah. Tentunya menimbulkan rasa antusias yang tinggi untuk kembali bertemu teman, belajar bersama, bahkan bersenda gurau bersama saat jam istirahat, tetapi tidak sama seperti sebelum pandemi. Siswa tetap harus mematuhi protokol kesehatan. Salah satunya dengan tidak membuat kerumunan atau menjauhi kerumunan demi kebaikan bersama.

\section{Mengurangi Mobilitas}

Mengurangi mobilitas artinya mengurangi menghabiskan waktu di luar rumah. Jadi, semakin banyak kita menghabiskan waktu di luar rumah, maka semakin tinggi pula kemungkinan kita terpapar virus covid-19. Oleh sebab itu, bila tidak ada keperluan yang mendesak, tetaplah berada di rumah. Begitu pula bagi peserta didik setelah pulang sekolah langsung pulang ke rumah tidak dianjurkan untuk jalanjalan keluar berkumpul dengan teman dan lain sebagainya.

\section{Pengawasan Pembelajaran Tatap Muka (PTM) Terbatas}

Fungsi pengawasan merupakan salah satu aspek penting dalam pembelajaran tatap muka (PTM) terbatas karena jika lembaga pendidikan lengah sedikit saja maka berpotensi terciptanya cluster baru penyebaran Covid-19. Apalagi model pembelajaran tatap muka (PTM) terbatas merupakan hal yang baru yang pastinya masih tahap uji coba. Setiap lembaga pendidikan belum mempunyai pengalaman dalam menerapkan pembelajaran tatap muka (PTM) terbatas. Instruksi pemerintah untuk melaksanakan pembelajaran tatap muka (PTM) terbatas harus dijalankan walaupun setiap lembaga pendidikan belum tentu siap untuk melaksanakannya. Pemerintah daerah harus membuat aturan yang jelas mengenai mekanisme pengawasan pembelajaran tatap muka (PTM) terbatas. Pengawasan pembelajaran tatap muka (PTM) terbatas minimal harus diadakan, instrumen, Evaluasi, dan pelaporan [32].

\section{Pelaksanaan Pemantauan}

Pemantauan harus dilaksanakan mulai dari jenjang pendidikan terendah sampai pada jenjang pendidikan tertinggi. Pemerintah membentuk tim pemantauan dengan membuatkan surat perintah tugas untuk turun ke lapangan mulai dari tingkat satuan pendidikan, kecamatan, kabupaten / kota, dan provinsi.

Pemantauan tingkat satuan pendidikan misalnya dapat dilakukan oleh tim pemantau internal. Lembaga pendidikan membuat satuan pemantau internal untuk melakukan pengawasan pembelajaran tatap muka (PTM) terbatas. Tim pemantau paling tidak terdiri dari kepala sekolah, kepala TU, dan tenaga kependidikan. Demikian juga pemantauan yang dilakukan oleh tim dari kecamatan, dimana tim ini dibentuk untuk melakukan pengawasan pada pembelajaran tatap muka (PTM) terbatas di lembaga pendidikan yang berada di kecamatan tersebut. Pemantau ini dapat dilakukan dengan pembentukan tim pengawasan di tingkat kecamatan dimana anggota timnya terdiri dari kepala satuan pendidikan yang berada di kecamatan tersebut, pengawasan pendidikan, dan dewan pendidikan.

Lebih jauh lagi, pengawasan dapat dilakukan oleh tingkat diatasnya seperti pengawasan yang dilakukan oleh tim dari kabupaten / kota. Pengawasan yang dilakukan pada tingkat kabupaten / kota memiliki jangkauan yang lebih luas. Pengawasan yang dilakukan oleh tim dari kabupaten / kota harus memiliki anggota tim yang lebih komplit dari berbagai macam latar belakang keahlian. Pemantau ditingkat ini harus melibatkan dinas pendidikan, dinas kesehatan, dinas sosial, dan pengawas pendidikan.

\section{Instrumen dan Evaluasi}

Instrumen yang harus disiapkan berkaitan dengan pengawasan dan evaluasi pembelajaran tatap muka (PTM) terbatas minimal meliputi pendidik dan tenaga kependidikan, peserta didik, sarana dan prasarana, SOP pelaksanaan, instrumen supervisi akademik, instrumen supervisi RPP. Artinya dalam melakukan pengawasan dan evaluasi tidak hanya mengawasi dan mengevaluasi peserta didik dan 
pendidiknya dalam penerapan protokol kesehatan, namun semua hal yang berkaitan dengan pembelajaran tatap muka (PTM) terbatas.

Pendidikan dan tenaga kependidikan diawasi dan dievaluasi tentang penerapan protokol kesehatan, demikian juga dengan vaksinasi, kesiapan mengajar dan melayani peserta didik. Demikian juga dengan peserta didiknya, harus diawasi dan dievaluasi tentang protokol kesehatannya, cara pemakaian masker, menjaga jarak didalam kelas maupun diluar kelas, dan intensitas mencuci tangan maupun menggunakan hand sanitizer.

Sarana dan prasarana juga perlu diawasi dan dievaluasi mengingat dalam pembelajaran tatap muka (PTM) terbatas perlu penerapan protokol kesehatan. Maka sarana dan prasarana pendidikan di dalam kelas maupun diluar kelas harus menjadi instrumen dalam melakukan pengawasan dan pengevaluasian. Memantau sarana mencuci tangan di depan kelas, memantau kursi dan meja yang sudah berjarak minimal satu meter, memantau kesiapan masker di lembaga pendidikan. SOP pelaksanaan juga perlu diawasi karena bisa jadi lembaga pendidikan abai dalam menerapkan SOP pembelajaran tatap muka (PTM) terbatas.

Berikutnya, yang perlu diawasi dan dievaluasi juga yaitu yang berkaitan dengan supervisi akademik dan RPP. Mengingat dalam pembelajaran tatap muka (PTM) terbatas pembelajaran dilakukan tidak sama dengan pembelajaran normal sehingga ada pengurangan hari dan jam pelajaran di lembaga pendidikan. Pengawasan dan pengevaluasian akademiknya berkaitan dengan jadwal pelajaran, hari masuk sekolah, sistem pembagian peserta didik sehingga mengurangi mobilitas, sampai pada persiapan pembelajaran tatap muka (PTM) terbatas dengan melakukan penyemprotan desinfektan dan kebersihan lingkungan akademik. Pengawasan dan pengevaluasian RPP juga perlu dilakukan sehingga kurikulum dan tujuan pendidikan dapat tercapai mengingat pedoman pembelajaran tatap muka (PTM) terbatas mengisyaratkan kepada lembaga pendidikan untuk mengurangi materi pelajaran dengan mengutamakan pembahasan yang pokok saja.

\section{Pelaporan}

Pada tahap ini merupakan tahap akhir dari pelaksanaan pengawasan dalam pembelajaran tatap muka (PTM) terbatas. Tim yang ditugaskan melakukan pengawasan melakukan pelaporan secara berkala dan berjenjang sesuai hasil pengawasannya. Tim pengawas tingkat sekolah melakukan pelaporan kepada kepada tim pengawasan yang berada di tingkat kecamatan domisili lembaga pendidikannya. Tim pengawas tingkat kecamatan melakukan pelaporan kepada tim yang berada di tingkat dinas pendidikan yang berada di kota / kabupaten sesuai wilayah kerja tim pengawasan kabupaten / kota. Tim pengawasan di tingkat kabupaten / kota juga melakukan pelaporan berjenjang dan berkala ke tingkat di atasnya yaitu dinas pendidikan provinsi, dimana pada akhirnya pelaporan dari tingkat satuan pendidikan sampai pada tingkat provinsi tersebut akan diakhiri di gubernur setempat.

Dari laporan-laporan pembelajaran tatap muka (PTM) terbatas tersebut kemudian akan menjadi saran dan masukan bagi gubernur untuk melakukan langka-langkah strategis demi efektif dan efisiennya pelaksanaan pembelajaran tatap muka (PTM) terbatas pada masa pandemi Covid-19. Dari laporan tersebut juga dapat menjadi pertimbangan, apakah pelaksanaan pembelajaran tatap muka (PTM) terbatas dapat dilanjutkan pada semester selanjutnya atau kembali pada model pembelajaran online atau belajar dari rumah.

\section{KESIMPULAN}

Kesimpulan dari artikel berkenaan dengan konsep pelaksanaan pembelajaran tatap muka (PTM) terbatas pada masa pandemi Covid-19 yaitu konsep pembelajaran tatap muka terbatas merupakan model pembelajaran yang dilaksanakan di lembaga pendidikan secara tatap muka yang dibatasi pada jumlah siswa, jumlah pertemuan, jam pertemuan dan materi pelajaran dengan syarat dan ketentuan yang telah ditetapkan dimana segala proses pembelajaran diminimalisir namun tidak mengurangi esensi dan tujuan pokok dari pembelajaran. Selanjutnya manajemen pembelajaran tatap muka terbatas tidak bisa dilepaskan dari fungsi-fungsi manajemen, yaitu perencanaan, pengorganisasian, pelaksanaan, dan pengawasan. Manajemen pelaksanaan pembelajaran tatap muka terbatas dilaksanakan dengan perencanaan yang matang, pengorganisasian yang tepat, pelaksanaan yang efektif dan efisien, serta pengawasan yang intens dengan melakukan pemantauan, adanya instrumen evaluasi, dan pelaporan. Harapannya melalui artikel ini pelaksanaan pembelajaran tatap muka terbatas dapat dilaksanakan sesuai dengan harapan, dan mampu memberikan saran perbaikan. 


\section{REFERENCES}

[1] O. P. Limbong, W. Tambunan, and M. Limbong, "Kesiapan Pelaksanaan Pembelajaran Tatap Muka Di SMK Negeri 2 Toraja Utara Pada Masa Pandemi," J. Manaj. Pendidik., vol. 10, no. 1, pp. 37-45, 2021.

[2] Z. D. Ulfa and U. Z. Mikdar, "Dampak Pandemi Covid-19 terhadap Perilaku Belajar, Sosial dan Kesehatan bagi Mahasiswa FKIP Universitas Palangka Raya," JOSSAE (Journal Sport Sci. Educ., vol. 5, no. 2, pp. 124-138, 2020.

[3] J. Soraya and D. Yuherawan, "Mengawal Mutu Pendidikan Bagi Siswa sebagai bentuk Perlindungan Hukum atas Hak Anak atas Pendidikan Pada Masa Transisi Pandemi Covid 19," Simp. Huk. Indones., vol. 2, no. 1, pp. 48-57, 2021.

[4] N. Nurmawati, "Model Discovery Learning pada PTMT Meningkatkan Hasil Belajar IPA Siswa Kelas IX-2 SMPN 1 Pasir Penyu,” J. Pendidik. Tambusai, vol. 5, no. 3, pp. 8424-8432, 2021.

[5] Kementerian Pendidikan dan Kebudayaan RI, "Panduan Penyelenggaraan Pembelajaran Pada Tahun Ajaran 2020/2021 dan Tahun Akademik 2020/2021 di Masa Pandemi Corona Virus Disease 2019 (Covid-19),” vol. 516. p. $95,2020$.

[6] A. Nurrachmawati, L. Permana, and R. T. Agustini, "Pendampingan dan Fasilitasi dalam Mempersiapkan Pertemuan Tatap Muka Terbatas Sesuai Protokol Kesehatan di SDN 001 Sungai Kunjang Kota Samarinda," JATI EMAS (Jurnal Apl. Tek. dan Pengabdi. Masyarakat), vol. 5, no. 3, pp. 79-84, 2021.

[7] C. Anam, "Analisis Kesiapan Pendidikan Vokasi Dalam Menyongsong Pembelajaran Tatap Muka Di Masa Pandemi Covid 19 (Studi Kasus di LP3I Malang)," J. Vokasi, vol. 5, no. 2, pp. 112-118, 2021.

[8] Y. Harahap, N. H. A. Nasution, and F. R. Lubis, "Persepsi Masyarakat Terhadap Kebijakan Pemerintah Tentang Pembelajaran Tatap Muka Terbatas Pada Kota Padangsidimpuan,” J. LPPM, vol. 11, no. 4, pp. 6976, 2021.

[9] B. Indrawati, “Tantangan dan Peluang Pendidikan Tinggi Dalam Masa dan Pasca Pandemi Covid-19,” J. Kaji. Ilm., vol. 1, no. 1, pp. 39-48, 2020.

[10] N. W. Powa, W. Tambunan, and M. Limbong, “Analisis Persetujuan Orang Tua Terhadap Rencana Pembelajaran Tatap Muka Terbatas Di SMK Santa Maria Jakarta,” J. Manaj. Pendidik., vol. 10, no. 2, pp. $100-111,2021$.

[11] D. Marlina, M. Marjuki, N. C. Sandhy, N. R. Alifah, and Z. N. Maryam, "Sosialisasi dan Edukasi Pencegahan Covid-19 Sebelum Memasuki Pembelajaran Tatap Muka di Desa Cipayung," Pros. Dedik. Pengabdi. Mhs. Kpd. Masy., vol. 1, no. 1, pp. 126-131, 2021.

[12] H. Palinggi and W. Tambunan, "Analisis Sistem Manajemen Pembelajaran Tatap Muka," J. Manaj. Pendidik., vol. 10, no. 01, pp. 21-27, 2021.

[13] L. Ode et al., "Analisis Pelaksanaan Pembelajaran Tatap Muka Terbatas (TMT) di masa New Normal terhadap Hasil Belajar Matematika di Sekolah Dasar," EDUKATIF J. Ilmu Pendidik., vol. 3, no. 6, pp. 44004406, 2021.

[14] S. Mujlauwidzatul Husna, "Eksplorasi Penerapan Pembelajaran Tatap Muka Terbatas pada Jenjang PAUD di Masa Kebiasaan Baru," J. Obs. J. Pendidik. Anak Usia Dini, vol. 6, no. 3, pp. 1846-1858, 2022, doi: 10.31004/obsesi.v6i3.1814.

[15] S. Sugiyono, Metode penelitian kualitatif. Bandung: Alfabeta, 2013.

[16] A. Rukajat, Pendekatan Penelitian Kualitatif (Qualitative Research Approach). Yogyakarta: Deepublish, 2018.

[17] A. Mirzaqon and B. Purwoko, "Studi Kepustakaan Mengenai Landasan Teori dan Praktik Konseling Expressive Writing,” J. BK Unesa, vol. 8, no. 1, pp. 1-8, 2018.

[18] A. F. Sabiq, "Persepsi Orang Tua Siswa tentang Pembelajaran Tatap Muka pada Era New Normal Pandemi Covid-19,” J. Islam. Educ. Res., vol. 1, no. 3, pp. 179-189, 2020.

[19] W. Utari, V. Y. Hikmawati, and A. A. Gaffar, "Blended Learning: Strategi Pembelajaran Alternatif di Era New Normal," in Prosiding Seminar Nasional Pendidikan, 2020, vol. 2, pp. 262-269.

[20] E. Pattanang, M. Limbong, and W. Tambunan, "Perencanaan Pelaksanaan Pembelajaran Tatap Muka Di Masa Pandemi Pada Smk Kristen Tagari,” J. Manaj. Pendidik., vol. 10, no. 2, pp. 112-120, 2021, doi: 10.33541/jmp.v10i2.3275.

[21] R. Mubarok, "Pelaksanaan Fungsi-Fungsi Manajemen Dalam Peningkatan Mutu Lembaga Pendidikan Islam,” Al-Rabwah, vol. XIII, no. 1, pp. 27-44, 2019.

[22] Yasin Muhammad, "Sosiologi Pendidikan Sebagai Basis Manajemen Pendidikan Dalam Penguatan Karakter Siswa," Al - Rabwah, vol. XIII, no. 2, pp. 1-23, 2019.

[23] W. Astuty and A. W. B. Suharto, "Desain Perencanaan Pelaksanaan Pembelajaran Pendidikan Agama Islam Lisensi: Creative Commons Attribution 4.0 International (CC BY 4.0) 
Daring dengan Kurikulum Darurat,” J. Penelit. Pendidik. Islam, vol. 9, no. 1, pp. 81-96, 2021.

[24] A. Supriyanto and dkk Rozaq, "Uji Coba Persiapan Pembelajaran Tatap Muka Masa Normal Baru PAUD “ Tunas Bangsa 'Semarang,” J. Pengabdi. Pada Masy., vol. 6, no. 3, pp. 753-763, 2021.

[25] O. P. Limbong, W. Tambunan, and M. Limbong, "Kesiapan Pelaksanaan Pembelajaran Tatap Muka Di Smk Negeri 2 Toraja Utara Pada Masa Pandemi," J. Manaj. Pendidik., vol. 10, no. 1, pp. 37-45, 2021, doi: 10.33541/jmp.v10i1.3265.

[26] Q. Akyuni, "Pengorganisasian Dalam Pendidikan Islam,” J. Stud. Pemikiran, Ris. dan Pengemb. Pendidik. Islam, vol. 10, no. 2, pp. 95-96, 2018, [Online]. Available: http://jurnal.serambimekkah.ac.id.

[27] S. Mirfaqo, "Update Covid-19 Kutai Timur: Kasus Aktif Tersisa 19 Pasien," Tribun Kaltim, 2021. https://kaltim.tribunnews.com/2021/10/27/update-covid-19-kutai-timur-rabu-27-oktober-2021-kasus-aktiftersisa-19-pasien.

[28] I. Susilowati, R. F. Nurkhalim, and K. D. Jayanti, "Membudayakan Protokol Kesehatan Di Lingkungan Perumahan Demi Pengendalian Penyebaran Covid-19," J. ABDINUS J. Pengabdi. Nusant., vol. 5, no. 1, pp. 66-74, 2021.

[29] A. Kurniati, D. Triana, M. E. P. Yuliyanti, E. Rosana, and N. T. Salsabillah, "Sosialisasi Pemakaian Masker dan Pembagian Masker Dalam Rangka Pemutusan Rantai Penularan Covid-19 di Kota Bengkulu," Dharma Raflesia J. Ilm. Pengemb. dan Penerapan IPTEKS, vol. 19, no. 1, pp. 82-90, 2021.

[30] R. Nurani and W. D. Sari, "Pencegahan Penyebaran Covid-19," ARSY J. Apl. Ris. Kpd. Masy., vol. 1, no. 2, pp. 105-109, 2021.

[31] S. Aldilawati and R. Hidayat, "Edukasi Vaksinasi Covid-19 dan Penerapan 5M Dalam Menanggulangi Penularan Covid-19 di Desa Borisallo Kabupaten Gowa,” Idea Pengabdi. Masy., vol. 1, no. 02, pp. 59-63, 2021.

[32] T. Meriana and W. Tambunan, "Evaluasi Persiapan Sekolah Tatap Muka Di Tkk Kanaan Jakarta," J. Manaj. Pendidik., vol. 10, no. 1, pp. 1-12, 2021. 